\title{
Phillips and Wage Curves: Empirical Evidence from Bosnia and Herzegovina
}

\author{
Edo Omerčevićc ${ }^{1}$ and Elif Nuroğlu ${ }^{2}$ \\ ${ }^{1}$ Center for Advancement of Free Enterprise, Dr. Ćire Truhelke 10/A, 72000 Zenica, Bosnia And Herzegovina \\ ${ }^{2}$ Faculty of Economics and Administrative Sciences, Turkish-German University, Şahinkaya Caddesi 86, \\ Beykoz, 34820 Istanbul, Turkey
}

Correspondence should be addressed to Elif Nuroğlu; nuroglu@tau.edu.tr

Received 26 June 2014; Revised 17 August 2014; Accepted 17 August 2014; Published 31 August 2014

Academic Editor: Magda E. Kandil

Copyright (C) 2014 E. Omerčević and E. Nuroğlu. This is an open access article distributed under the Creative Commons Attribution License, which permits unrestricted use, distribution, and reproduction in any medium, provided the original work is properly cited.

\begin{abstract}
This study is an empirical examination of the existence and characteristics of the Phillips curve and the wage curve in Bosnia and Herzegovina. The findings indicate that there is no evidence of the existence of the short-term Phillips curve. Instead, the data suggests that in the short-term an increase in inflation leads to an increase in unemployment. The estimated wage curves indicate that only increases in real payment increase employment. The conclusion of this study is that increases in inflation might have a negative short-term impact on the level of employment in Bosnia and Herzegovina.
\end{abstract}

\section{Introduction}

This paper offers an insight on short-term effects of inflation on unemployment level in Bosnia and Herzegovina $(\mathrm{BiH})$. The relationship is tested on country level as well as individually on the level of its entities: Federation of Bosnia and Herzegovina, Republika Srpska, and Brčko District.

$\mathrm{BiH}$ has been chosen for this study because of its unique monetary arrangement, that is, the currency board system adopted in $\mathrm{BiH}$, fixing its exchange rate to the Euro and also due to the high unemployment rate that persists since the independence of the country. This type of monetary system results, of course, in a strong relationship with the European monetary system as well as the European Central Bank (ECB). The main goals of the ECB are to maintain price stability in the EU, to achieve a low-level of unemployment and to facilitate economic growth with low inflation. However, due to recent financial and economic events, mostly the financial crisis in Greece, and possible financial breakdowns in Spain and Italy, the commitment of the ECB to maintain low inflation is challenged by required bailouts of the EU member countries that face financial difficulties. Since Bosnia and Herzegovina operates within a currency board regime with its exchange rate fixed to the Euro, the inflation rate of $\mathrm{BiH}$ is expected to be a reflection of inflation in the $\mathrm{EU}$ (the correlation between the monthly CPI of Bosnia and Herzegovina and the EU amounts to 0.94 , based on a data sample of monthly CPI from April 2008 to June 2012). As a result, any change in monetary policy of the European Union (EU) might be a blessing or a curse for $\mathrm{BiH}$, depending on the country's inflation-unemployment relation. If the relation is negative, as proclaimed by supporters of the Phillips curve, a possible increase in inflation might decrease the high level of unemployment in the country which, at the end of 2012, amounted to $45 \%$ and was one of the highest unemployment levels in the world. However, if the inflation-unemployment relationship is positive, a higher inflation rate in the $\mathrm{EU}$ might indeed burden the economy of $\mathrm{BiH}$ further and as a result even increase pressure on employment. This possible negative long-term effect of inflation on unemployment has been highlighted by Ahrens and Snower [1]. Moreover, estimating the extent of wage rigidity in $\mathrm{BiH}$ is important for understanding monetary policy transmission mechanism between the Euro area and $\mathrm{BiH}$ and to analyze whether wage curve mechanisms are also in force in post-war $\mathrm{BiH}$.

This analysis is done by inquiring about the inflationunemployment relation known as the Phillips curve, a central component of macroeconomics and a very important one 
for policymakers providing them with a basic constraint on policy. Should policy makers decide to stimulate the economy, the outcomes will be determined by the shape of the Phillips curve, which, if vertical, will indicate that there will be no lasting unemployment-inflation trade-off $[2,3]$. The concept represented by this curve is an essential building block of almost all (new) Keynesian macroeconomic models [4]. Empirical estimation of the wage curve is also covered in this study in order to search the response levels of employment to changing local labor market conditions, that is, the effect of changes in nominal versus real wage levels on employment. A wage curve represents a negative relationship between a worker's pay and unemployment rate [5], which is in contradiction with traditional thinking on the wage-unemployment relationship, in which wages and unemployment are assumed to be positively correlated [6-8]. It is also important to note that studies conducted on wage curve have pointed out that wage curve elasticity varies by worker characteristics $[9,10]$.

The contribution of this paper is to show the interplay of inflation and unemployment in Bosnia and Herzegovina by means of the Phillips and wage curves and then to reveal the impact of the European Central Bank's policies on the high levels of unemployment in Bosnia and Herzegovina. It is aimed at providing the policy makers with an insight about the reactions to the moves chosen by the European Central Bank in the economy of $\mathrm{BiH}$.

The plan of the paper is as follows. Section 2 gives an overview of the literature. Section 3 mentions the methodology and introduces the data set used to estimate the Philips and wage curves in $\mathrm{BiH}$. Section 4 shows and interprets the findings, and finally Section 5 concludes.

\section{Literature Review}

The foundation for what we know today as the negative inflation-unemployment relation was laid down by Phillips who published his findings on the relationship between money wage rates and unemployment in 1958, using annual data from the United Kingdom covering the period from 1861 to 1957 [11, 12]. Philips considered the periods 1861-1913 (preworld war), 1913-1948 (interwar), and 1948-1957 (post-world war) separately and in all of them found empirical evidence for the relationship between two factors. He specifically concluded that "the rate of change of money wage rates can be explained by the level of unemployment and the rate of change of unemployment" [12]. According to him, this was a stable, century-long, and inverse relation between the rate of change of money wage rates and unemployment. Since it offers a choice between employment and inflation to the policy makers, the Philips curve gained high importance in that and following decade [13]. Politicians easily adopted the trade-off interpretation of the Philips curve and used it as an explanation for expansionary macroeconomic policies applied to fight the unemployment [14]. Brown [15] previously tested the same orthodox data set for the same cycles and found an inverse relationship between inflation and unemployment; however, according to his findings, the inflation-unemployment relation was variable in size for each cycle. The reason why Brown could not see a general relation but Philips did is explained by Wulwick [16] that Phillips simplified the scatter diagram by applying a regression method which was called double process of simplification and was criticized by his opponents saying that Philips "has exaggerated the closeness of the relation that it reveals" [17].

Samuelson and Solow [18] tested the American data for the trade-off between inflation and unemployment in the USA, whereby the results did not contradict the conclusions based on the UK data, "although they do not tell as plain a story as the English" (p. 190). Post-Keynesians such as Sydney [19] did not accept unemployment as an answer to inflation since it would contradict their social philosophy.

Phelps [20] further developed the relationship by explaining how a reduction of frictional unemployment is achieved, at least in the short-term, with inflation. In short, the workers are motivated with nominal increases in wages, whereby they do not adjust their real incomes for inflation. Hence there is a short-term correlation between the rate of wage change and the unemployment rate. However, the condition for this effect to take place is that expectations about inflation are incorrect. This motivated policy makers to assume that they could exploit this trade-off to reduce unemployment at a small cost of additional inflation. Friedman [21] criticized this exploitation of the short-term inflation-unemployment trade-off, remarking that the temporary trade-off between inflation and unemployment "comes not from inflation per se, but from unanticipated inflation, which generally means, from a rising rate of inflation." However, there is no permanent trade-off; hence governments should not employ the policy to stimulate employment with inflation. Meade and Thornton [22] investigate the role that the Phillips curve framework played in Federal Reserve policymaking from 1979 to 2003. They show that "the Phillips curve framework appears to have played a much less prominent role in Fed policymaking than it does in macroeconomic models used to evaluate Fed policy." They reviewed 25 years of meeting transcripts to see the extent to which policymakers and staff employed the Phillips curve framework in order to make policy and formulate inflation forecasts. They find an infrequent use of the Phillips curve framework by policymakers and conclude that the role the Philips Curve plays in the formulation of monetary policy appears to have been limited.

More recent studies confirm the existence of the Phillips curve and its short-term nature as explained by Friedman [21]. The study by Malinov and Sommers [23] found that the Phillips curve is evident and stable in the short-run for many OECD countries, but they also found that the relationship for the United States deteriorated since 1970s. However, Naghdi et al. [24] tested the Phillips curve hypothesis for Iran and actually claim to have found a long-term inverse relationship between inflation and unemployment rate. The long-term relationship has been also noted by Tang and Lean [25] whose investigation suggested that there is a trade-off between inflation and unemployment in Malaysia, both, in the shortand long-term. Çatik et al. [26] found no evidence of a longterm relationship for Turkey, but by including the variance 
and skew of the relative price changes, the error correction model implies a plausible short-term relationship.

Conversely, Niskanen [27] and Reichel [28] argue that the concept of the Phillips curve should indeed be buried and that as a policy guideline it is totally useless. Niskanen [27] goes even further and claims that the relationship between inflation and unemployment is positive in the long-term; that is, inflation creates unemployment if the inflation rate is lagged one year (based on the US data). This is confirmed by the study of Haug and King [3] who estimated the longrun vertical Phillips curve in the US using a band-pass filter approach. They found strong evidence that a positive relationship exists in which inflation leads to unemployment in 3-3.5 years, occurring in cycles that last from 8 to 25 or 50 years. However in the short-run, Kajuth [4] found an economically significant trade-off between inflation and the unemployment gap for the US and an even more significant one for the Euro area. de Mendonça [29] analyzes the adoption of inflation targeting in Brazil and finds that there is no unemployment-inflation trade-off even in the short run.

On the other hand, Baltagi et al. [30] analyze the period 1980-2004 for West German wage curve and conclude that the wage equation is not a pure Philips curve but it is a dynamic wage curve. Granger and Jeon [31] adopt a timevarying parameter linear model similar to Philips' model and apply this to four different economies that are the US, the UK, Australia, and Turkey. They conclude that the basic relationship found by Phillips is still there in a nonlinear form but with changing coefficients. According to them, the causation is one way and nonlinear, from unemployment to inflation but not in reverse direction.

Studies on the wage curve find the wage curve to be stable around an unemployment elasticity of the wage about -0.1 [32]. However, wage elasticity might differ across regions, as shown in a study conducted by Montuenga et al. [33] on five EU countries using information provided by a homogeneous panel data set-the European Community Household Panel on France, Italy, Portugal, Spain, and the UK for the period 1994-96. The results indicate that wages in different countries seem to exhibit a differing degree of response in the face of changes in the unemployment rate. Sanz-de-Galdeano and Turunen [9] used longitudinal micro data to examine wage curve for the euro area over the period 1994-2001 and found that wage elasticity varies across groups of workers; in particular, wages of public sector workers are substantially less responsive to the regional unemployment rate. Baltagi et al. [34] found in their study on West Germany conducted over the period 1980-2004 that bargaining power also influences wage elasticity, that is, that younger versus older workers, men versus women, and foreigners versus native Germans have a more pronounced wage effect of unemployment. Some studies even fail to find a clear negative relationship between wages and unemployment. Pannenberg and Schwarze [35] conducted a study on East Germany for a period from 1992 to 1994 and reported a result that there is no significantly negative relationship between regional wages and regional unemployment for East Germany while Johnes [32] ended up with an unemployment elasticity of the wage for the UK (for a period from 1992 to 2003) that is both volatile and imprecisely determined and a shape that "does not generally accord with any general empirical law" [32, p. 419].

\section{Methodology and Data}

This study is on the existence and characteristics of the Phillips curve in Bosnia and Herzegovina at the national level and covers the period from April 2008 to June 2012. To overcome the problem of small-sample-size, monthly data is used for a total of 51 observations. Usually, annual data is preferred for this type of study, but some also used monthly data [36, 37]. The variables used are unemployment rate and CPI, whereby unemployment data was obtained from the Directorate for Economic Planning, while CPI data was obtained from the Agency for Statistics of Bosnia and Herzegovina. Between 2008 and 2010, CPI base year was 2005. For 2011, the base year was 2010, while for the monthly CPI data in 2012, the base months were the previous months. To prepare the data for the regressions, all the CPI data has been converted to 2005 as the base year. OLS regression has been used to estimate the coefficients for the Phillips curve, based on the model in

$$
\ln i=c+\beta_{1} \ln u n+e_{t} .
$$

$c$ is the constant coefficient and $\beta_{1}$ is the slope coefficient, $\ln (i)$ is representing the natural logarithm of the inflation rate, and $\ln (u n)$ is representing the natural logarithm of the unemployment rate while $e$ denotes the error term. We note that many empirical studies on the Phillips curve use price growth rate as inflation rate. However, in this study, we follow de Brouwer and Ericsson [38] and Salman and Shukur [39] who use the natural log of CPI as a proxy for the inflation rate. The standard specification Phillips curve relates the inflation rate to the unemployment rate and other scale variables such as real GDP and marginal cost of production. The alternative specification considers the output gap or the real output as a proxy for the unemployment rate. However, for this study we used (1) for estimating the relationship between the inflation rate and the unemployment rate.

In order to determine the wage curve, the original model outlined by Phillips [12] is used:

$$
\ln w=c+\beta_{1} \ln u n+e_{t},
$$

where $\ln (w)$ is the natural logarithm of nominal average net payment (nominal payment) and $\ln (u n)$ is the natural logarithm of unemployment, while $e$ denotes the error term. In addition to the analysis of nominal payment, the relationship between inflation adjusted average net payment (real payment) and unemployment will also be provided:

$$
\ln w r=c+\beta_{1} \ln u n+e_{t} .
$$

In (3), $\ln (w r)$ is the natural logarithm of the real payment. In order to estimate the wage curve, the data will be divided into the country level, Federation of Bosnia and Herzegovina (FBiH), Republika Srpska (RS), and Brčko District (BD) (the reason why this has not been done with the Phillips curve analysis is because CPI data was available for country level 
TABLE 1: Regression results for the wage curve.

\begin{tabular}{lc}
\hline & Phillips curve BiH \\
\hline Constant ( $t$-statistics) & $5.58^{*}(63.75)$ \\
$\ln$ (unemployment rate) $(t$-statistics) & $0.95^{*}(9.21)$ \\
$R^{2}(\%)$ & 63.37 \\
$F$-statistics & 84.76 \\
Number of observations & 51 \\
\hline
\end{tabular}

* Significant at $1 \%$ critical value.

only). Average net payment data and required unemployment rates were obtained from the Directorate for Economic Planning. Because of different data structure, the data for the country level will be the same as for the Phillips curve analysis, that is, April 2008 to June 2012. For FBiH, the data set is also based on monthly observations as well, covering a longer period, that is, from January 2006 to June 2012, totaling 78 observations. The data for RS is semiannual data and ranges from March 2006 to March 2012 providing 13 observations, while the data for BD is quarterly, starting from March 2006 to March 2012 providing 25 observations (one quarter is missing).

\section{Findings}

The regression results of the Phillips curve model shown in Table 1 indicate that there is no inverse inflation-unemployment relation in $\mathrm{BiH}$ as expected by the Phillips curve supporters. The results show indeed a positive relationship between inflation and unemployment, whereby the coefficient of the independent variable is significant at $1 \%$ critical value, and, according to the $F$-statistics, the overall model is significant as well. $R^{2}$ amounts to $63.37 \%$ and the goodness of fit of the regression is in line with de Mendonça [29] who obtained an adjusted $R$-squared ranging from 73 to $78 \%$ and Çatik et al. [26] who reported an $R$-squared of $76.5 \%$. The model has been tested for heteroskedasticity using the Breusch-Pagan/Cook-Weisberg test which indicates that the model has constant variance. The regressor unemployment indicates that a $1 \%$ increase in unemployment results in a $0.94 \%$ increase in inflation or, inversely, $1 \%$ inflation is related to a $1.06 \%$ increase in unemployment. However, given that our dataset consists of monthly observations, the findings are only about the short-term inflation-unemployment relationship.

The estimation results of the wage curves (nominal and real) are also very interesting. As shown in Table 2, at country level, the regressor unemployment is positive against the nominal payment, whereby the coefficient of the independent variable is significant at $1 \%$ critical value and so is the overall model, as indicated by $F$-statistics. $R$-squared amounts to $66.50 \%$ and the model has constant variance at $1 \%$ critical value (see Table 3 ). The regressor unemployment indicates that $1 \%$ increase in unemployment results in $0.907 \%$ increase in nominal pay or, inversely, $1 \%$ increase in nominal pay is related to $1.10 \%$ increase in unemployment. Contrary to the findings using short-term nominal data, real payunemployment relationship indicates a negative relationship. However, as indicated by the two-way scatter graph (see Figure 1), a quadratic model needs to be used for the estimation process. As shown in Table 2, the quadratic model is statistically significant, and the model does not suffer from heteroskedasticity (see Table 3 ). The coefficients indicate that there is a negative relationship, but at a decreasing rate. Thus, a fall in unemployment is linked with an increase in real payment. It is important to note that the correlation between nominal and real payment at country level amounts to a low 0.24. This might also explain the varying results between the nominal and real pay-unemployment relationship. Thus, decreases in unemployment are caused only by real payment increases. Hence, inflation fueled increases in nominal wages without a corresponding increase in real wages might not improve employment levels, not even in the short term.

The estimation results for $\mathrm{FBiH}$ are different from those found at the country level. Thus, for both nominal and real pay-unemployment relationship the coefficients are negative (see Table 2). Both estimations have a constant variance (see Table 3). Contrary to the country level, in $\mathrm{FBiH}$ the correlation between nominal and real payment amounts to a high 0.95. Therefore, changes in nominal level are reflected in changes in real payments as well. Hence, an inflation induced increase in average net payment might not lead to any increase in employment levels, which is in line with our findings regarding the (non) existence of the Phillips curve.

It is also interesting to note that for RS there seems to be no relationship between average net payment (nominal or real) and unemployment, as indicated by the two-way scatter graphs (see Figures 2 and 3). That is also reflected in the estimation coefficients, all being statistically insignificant (see Table 2). The inconclusiveness in the case of RS might be due to small sample size, given that we only have 13 semiannual observations, while for $\mathrm{BiH}$ and $\mathrm{FBiH}$ we have monthly data.

Regression results for $\mathrm{BD}$ result in a wage curve that indicates a high correlation between real and nominal payment. This is also confirmed by the correlation that amounts to 0.79. Thus, both nominal and real payment have a negative relationship with unemployment level (see Table 2). Furthermore, in $\mathrm{BD}$ it is actually only a change in real payment that stimulates employment. Changes in nominal wages only might not be effective.

\section{Conclusion}

This study provides an empirical analysis concerning the existence of the Phillips curve in $\mathrm{BiH}$ and the characteristics of the wage curve at four levels, that is, at the country level $(\mathrm{BiH})$, Federation of Bosnia and Herzegovina $(\mathrm{FBiH})$, Republika Srpska (RS), and Brčko District (BD). The findings indicate that Phillips curve is not existent in $\mathrm{BiH}$, meaning that an inflation induced increase in net payment does not stimulate the level of employment. The analysis of wage curves hints at the reality that only inflation adjusted wage 
TABLE 2: Regression results for the wage curve.

\begin{tabular}{|c|c|c|c|c|}
\hline & \multicolumn{4}{|c|}{ Linear wage curve (nominal average net pay) } \\
\hline & $\mathrm{BiH}$ & $\mathrm{FBiH}$ & RS & $\mathrm{BD}$ \\
\hline Constant ( $t$-statistics) & $7.45^{*}(94.97)$ & $4.29^{*}(18.05)$ & $2.04^{*}(19.67)$ & $6.22^{*}(260.44)$ \\
\hline $\ln$ (unemployment rate) ( $t$-statistics) & $0.91^{*}(9.86)$ & $-2.98^{*}(-9.75)$ & $0.15(1.47)$ & $-0.51^{*}(-14.56)$ \\
\hline$R^{2}(\%)$ & 66.50 & 55.55 & 16.39 & 80.85 \\
\hline$F$-statistics & 97.26 & 95.00 & 2.16 & 97.07 \\
\hline \multirow[t]{3}{*}{ Number of observations } & 51 & 78 & 13 & 25 \\
\hline & \multicolumn{4}{|c|}{ Linear wage curve (inflation adjusted average net pay) } \\
\hline & $\mathrm{BiH}$ & $\mathrm{FBiH}$ & RS & $\mathrm{BD}$ \\
\hline Constant ( $t$-statistics) & $-7.82^{* *}(-2.23)$ & $5.13^{*}(36.15)$ & $6.76^{*}(8.78)$ & $6.35^{*}(408.51)$ \\
\hline $\ln$ (unemployment rate) ( $t$-statistics) & $-33.39^{*}(-4.08)$ & $-1.72^{*}(-9.43)$ & $0.34(0.45)$ & $-0.16^{*}(-8.18)$ \\
\hline $\ln$ (unemployment rate squared) ( $t$-statistics) & $-19.44^{*}(-4.08)$ & - & - & - \\
\hline$R^{2}(\%)$ & 25.92 & 53.94 & 1.84 & 55.83 \\
\hline$F$-statistics & 8.40 & 89.00 & 0.21 & 29.08 \\
\hline Number of observations & 51 & 78 & 13 & 25 \\
\hline
\end{tabular}

${ }^{*}$ Significant at $1 \%$ critical value.

${ }^{* *}$ Significant at $5 \%$ critical value.

TABLE 3: Breusch-Pagan/Cook-Weisberg test for heteroskedasticity.

\begin{tabular}{|c|c|c|c|c|}
\hline & $\mathrm{Chi}^{2}$ & Prob $>$ chi $^{2}$ & Critical level & Conclusion \\
\hline & \multicolumn{4}{|c|}{ Linear Phillips curve } \\
\hline \multirow[t]{2}{*}{$\mathrm{BiH}$} & 0.00 & 0.9964 & $10 \%$ & Linear variance \\
\hline & \multicolumn{4}{|c|}{ Linear wage curve (nominal average net pay) } \\
\hline $\mathrm{BiH}$ & 5.44 & 0.0197 & $1 \%$ & Linear variance \\
\hline $\mathrm{FBiH}$ & 0.37 & 0.5425 & $10 \%$ & Linear variance \\
\hline RS & - & - & - & - \\
\hline \multirow[t]{2}{*}{$\mathrm{BD}$} & 2.31 & 0.1281 & $10 \%$ & Linear variance \\
\hline & \multicolumn{4}{|c|}{ Linear wage curve (inflation adjusted average net pay) } \\
\hline $\mathrm{BiH}$ & 0.13 & 0.7139 & $10 \%$ & Linear variance \\
\hline $\mathrm{FBiH}$ & 0.17 & 0.6823 & $10 \%$ & Linear variance \\
\hline RS & - & - & - & - \\
\hline $\mathrm{BD}$ & 0.27 & 0.6041 & $10 \%$ & Linear variance \\
\hline
\end{tabular}

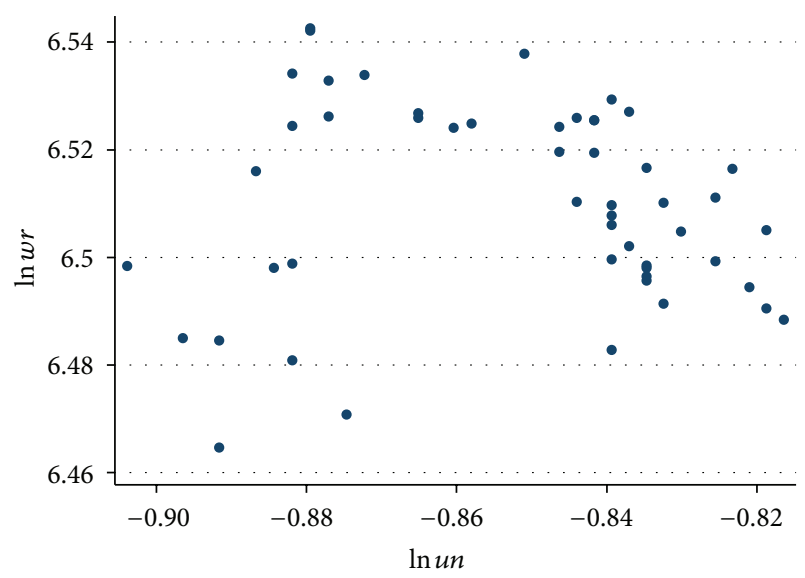

Figure 1: Two-way scatter graph $(\ln w r$ and $\ln u n)$ for $\mathrm{BiH}$.

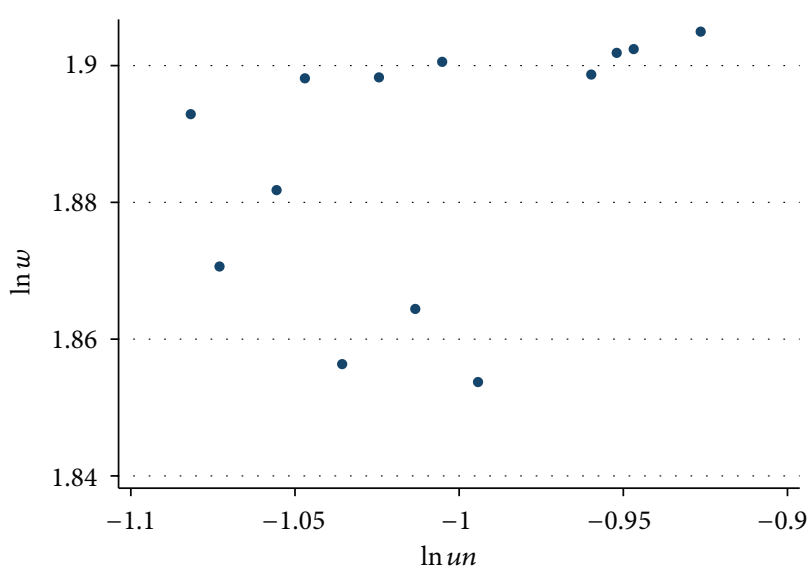

Figure 2: Two-way scatter graph ( $\ln w$ and $\ln u n)$ for RS. 


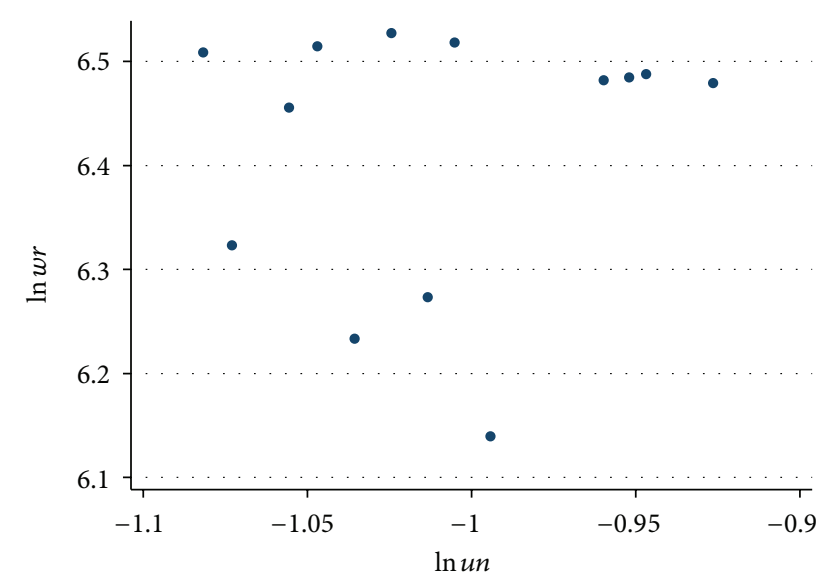

FIGURE 3: Two-way scatter graph ( $\ln w r$ and $\ln u n)$ for RS.

increases stimulate employment. Given that $\mathrm{BiH}$ is under a currency regime, whereby the inflation of the Euro area is highly reflected in the inflation rate in $\mathrm{BiH}$, the country needs to follow the steps of the European Central Bank with concern. If it chooses an expansionary monetary policy to stimulate the economy of the EU and to assist member countries that are facing financial and liquidity difficulties, to such an extent that inflation rates increase, the effect on BiH's population might even be negative if the increase in inflation results in a decline in real wages.

\section{Limitations and Possible Areas of Research}

The sample chosen for this study is relatively small. This is directly reflected in the results for Republika Srpska, both model and coefficient estimates being statistically insignificant in the wage curve estimations. This limitation is caused by the unavailability of data making it impossible to estimate long-term effects and relationships between variables. The model used in the regression could also not be extended to include more explanatory variables, like GDP, simply because of unavailability of data.

In order to improve the understanding of inflationunemployment relation in $\mathrm{BiH}$, additional variables and data would definitely be welcomed. Moreover, it would be more interesting to perform a study about the ability of producers to channel nominal increases in costs to the consumers and see how this affects the adjustment of nominal payment level. Furthermore, it would be of considerable use to study inflation adjustment of social benefits and tax exemption levels and their adjustment to inflation, affecting directly the real pay/purchasing power of the population and consequently employment.

\section{Conflict of Interests}

The authors declare that there is no conflict of interests regarding the publication of this paper.

\section{References}

[1] S. Ahrens and D. J. Snower, "Envy, guilt, and the Phillips curve," Journal of Economic Behavior \& Organization, vol. v99, pp. 6984, 2014.

[2] T. Palley, "The economics of the Phillips curve: formation of inflation expectations versus incorporation of inflation expectations," Structural Change and Economic Dynamics, vol. 23, no. 3, pp. 221-230, 2012.

[3] A. A. Haug and I. King, "In the long run, US unemployment follows inflation like a faithful dog," Journal of Macroeconomics, vol. 41, pp. 42-52, 2014.

[4] F. Kajuth, "Identifying the Phillips curve through shifts in volatility," Journal of Macroeconomics, vol. 34, no. 4, pp. 975991, 2012.

[5] B. Bratsberg and J. Turunen, "Wage curve evidence from panel data," Economics Letters, vol. 51, no. 3, pp. 345-353, 1996.

[6] J. R. Harris and M. P. Todaro, "Migration, unemployment and development: a two-sector analysis," American Economic Review, vol. 60, pp. 126-142, 1970.

[7] E. Hall Robert, "Why is the unemployment rate so high at full employment?" Brookings Papers on Economic Activity, vol. 3, pp. 369-410, 1970.

[8] R. E. Hall, "Turnover in the Labor Force," Brookings Papers on Economic Activity, vol. 3, pp. 709-756, 1972.

[9] A. Sanz-de-Galdeano and J. Turunen, "The euro area wage curve," Economics Letters, vol. 92, no. 1, pp. 93-98, 2006.

[10] B. H. Baltagi, Y. S. Baskaya, and T. Hulagu, "The Turkish wage curve: evidence from the Household Labor Force Survey," Economics Letters, vol. 114, no. 1, pp. 128-131, 2012.

[11] R. J. Gordon, "The history of the Phillips curve: consensus and bifurcation," Economica, vol. 78, no. 309, pp. 10-50, 2011.

[12] A. W. Phillips, "The relation between unemployment and the rate of change of money wage rates in the United kingdom, 18611957," Economica, vol. 25, no. 100, pp. 283-299, 1958.

[13] R. Albert, "The phillips curve as a menu for policy choice," Economica, vol. 37, no. 147, pp. 227-238, 1970.

[14] A. G. Sleeman, "Retrospectives the phillips curve: a rushed job?" The Journal of Economic Perspectives, vol. 25, no. 1, pp. 223-238, 2011.

[15] A. J. Brown, The Great Inflation: 1939-1951, Oxford University Press, London, UK, 1955.

[16] N. J. Wulwick, "The Phillips curve: which? whose? to do what? how?" Southern Economic Journal, vol. 53, no. 4, pp. 834-857, 1987.

[17] G. Routh, "The relation between unemployment and the rate of change of money wages: a comment," Economica, pp. 299-315, 1959.

[18] P. A. Samuelson and R. M. Solow, "Analytical aspects of antiinflation policy," The American Economic Review, vol. 50, no. 2, pp. 177-194, 1960, Papers and Proceedings of the 72nd Annual Meeting of the American Economic Association.

[19] W. Sydney, "The Keynesian theory of inflation: the two faces of Janus?" International Economic Review, vol. 1, no. 2, pp. 143-155, 1960.

[20] E. S. Phelps, "Phillips curves, expectations of inflation and optimal unemployment over time," Economica, vol. 34, no. 135, pp. 254-281, 1967.

[21] M. Friedman, "The role of monetary policy," American Economic Review, vol. 57, no. 1, pp. 1-17, 1968. 
[22] E. E. Meade and D. L. Thornton, "The Phillips curve and US monetary policy: what the FOMC transcripts tell us," Oxford Economic Papers, vol. 64, no. 2, pp. 197-216, 2012.

[23] M. J. Malinov and P. M. Sommers, "A new line on the Phillips curve," Social Science Quarterly, vol. 78, no. 3, pp. 740-746, 1997.

[24] Y. Naghdi, S. Kaghazian, and S. Ghavidel, "The stability of phillips curve in Iran: rolling regression analysis," Australian Journal of Basic and Applied Sciences, vol. 5, no. 12, pp. 13981401, 2011.

[25] C. F. Tang and H. H. Lean, "Is the Phillips curve stable for Malaysia? New empirical evidence," Malaysian Journal of Economic Studies, vol. 44, no. 2, pp. 95-105, 2007.

[26] A. N. Çatik, C. Martin, and A. Ö. Onder, "Relative price variability and the Phillips curve: evidence from Turkey," Journal of Economic Studies, vol. 38, no. 5, pp. 546-561, 2011.

[27] W. A. Niskanen, "On the death of the Phillips curve," Cato Journal, vol. 22, no. 2, pp. 193-198, 2002.

[28] R. Reichel, "On the death of the phillips curve: further evidence," Cato Journal, vol. 24, no. 3, pp. 341-348, 2004.

[29] H. F. de Mendonça, "Output-inflation and unemploymentinflation trade-offs under inflation targeting: evidence from Brazil," Journal of Economic Studies, vol. 36, no. 1, pp. 66-82, 2009.

[30] B. H. Baltagi, U. Blien, and K. Wolf, "Phillips curve or wage curve? Evidence from West Germany: 1980-2004,” IAB Discussion Paper 14/2007, 2007.

[31] C. W. J. Granger and Y. Jeon, "The evolution of the Phillips curve: a modern time series viewpoint," Economica, vol. 78, no. 309, pp. 51-66, 2011.

[32] G. Johnes, "The wage curve revisited: estimates from a UK panel," Economics Letters, vol. 94, no. 3, pp. 414-420, 2007.

[33] V. Montuenga, I. García, and M. Fernández, "Wage flexibility: evidence from five EU countries based on the wage curve," Economics Letters, vol. 78, no. 2, pp. 169-174, 2003.

[34] B. H. Baltagi, U. Blien, and K. Wolf, "A dynamic spatial panel data approach to the German wage curve," Economic Modelling, vol. 29, no. 1, pp. 12-21, 2012.

[35] M. Pannenberg and J. Schwarze, "Labor market slack and the wage curve," Economics Letters, vol. 58, no. 3, pp. 351-354, 1998.

[36] B. T. Ewing and W. L. Seyfried, "A new line on the phillips curve. A comment," Social Science Quarterly, vol. 80, no. 1, pp. 193-196, 1999.

[37] J. E. Payne, T. L. Martin, and S. N. Potter, "A new line on the Phillips curve additional evidence on the U.S.", Social Science Quarterly, vol. 81, no. 2, pp. 678-680, June 2000.

[38] G. de Brouwer and N. R. Ericsson, "Modeling inflation in Australia," Journal of Business and Economic Statistics, vol. 16, no. 4, pp. 433-449, 1998.

[39] A. K. Salman and G. Shukur, "Testing for Granger causality between industrial output and CPI in the presence of regime shift: Swedish data," Journal of Economic Studies, vol. 31, no. 6, pp. 492-499, 2004. 

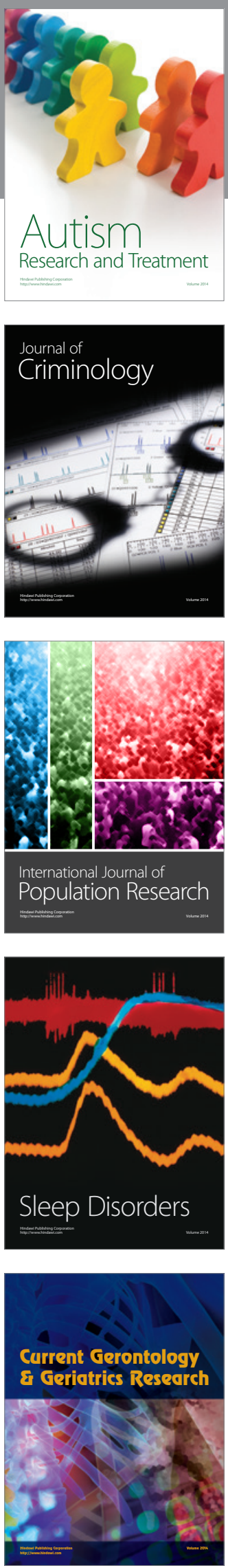
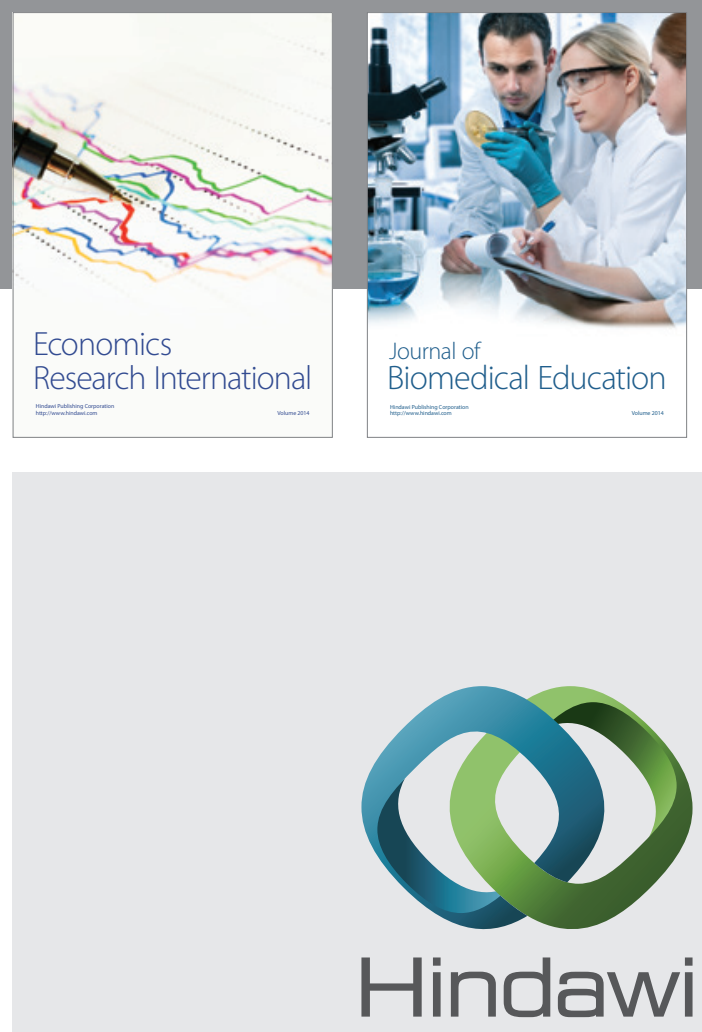

Submit your manuscripts at

http://www.hindawi.com
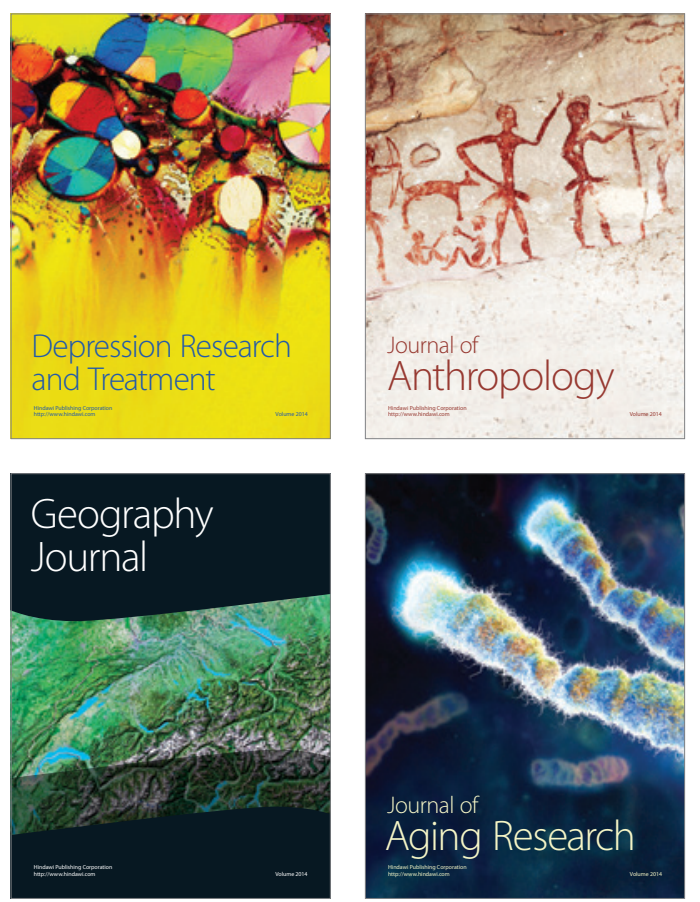
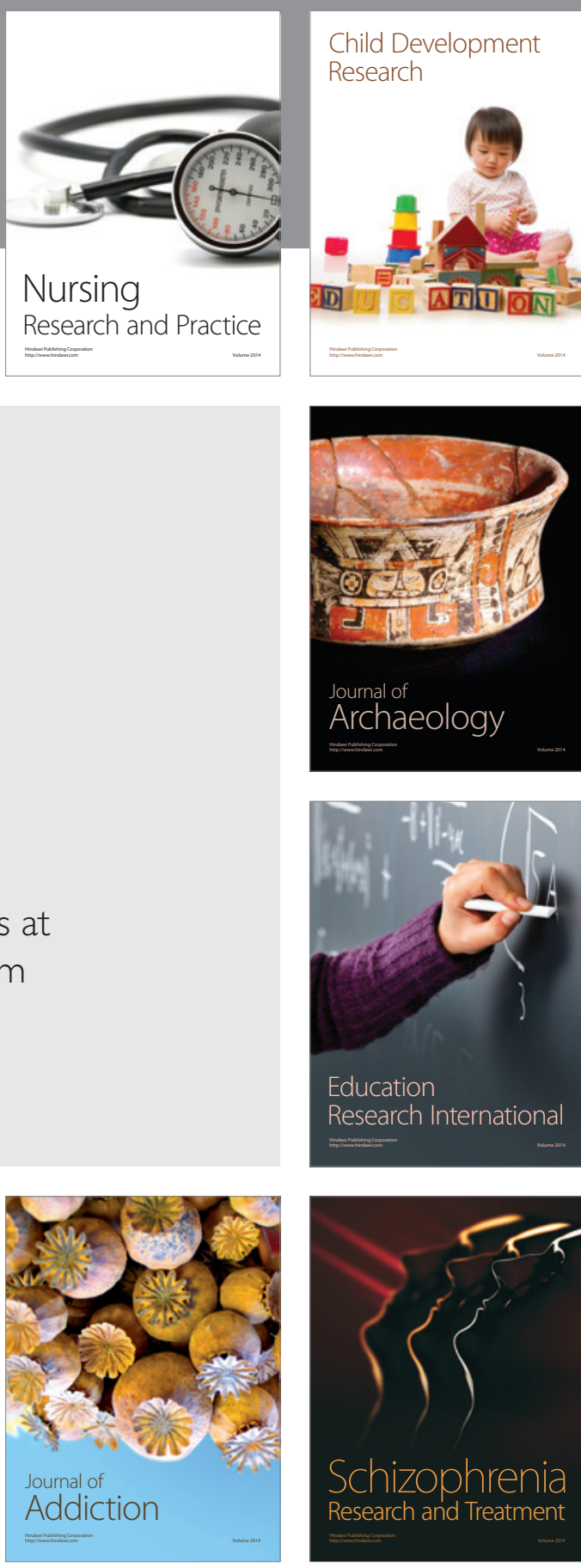

(D)
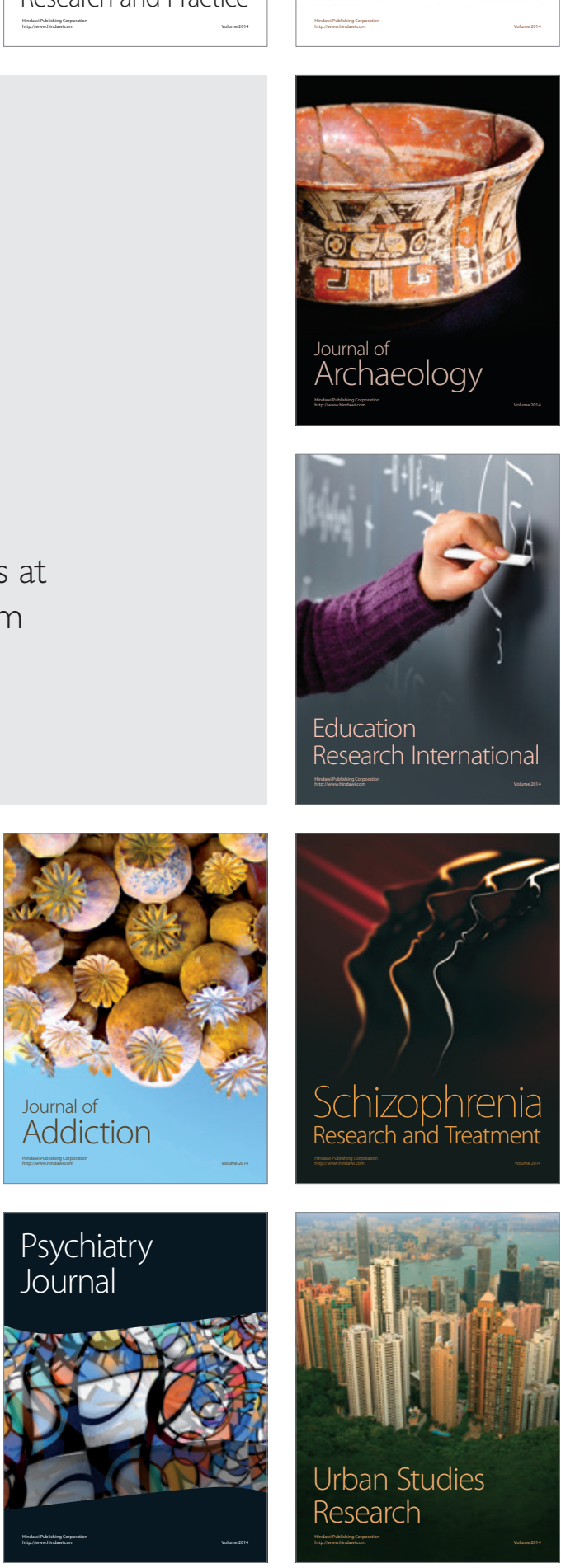